\title{
Desain Interior Sebagai Medium Komunikasi Nonverbal Restoran Eat Happens dalam Membentuk Reputasi
}

\author{
Rana Putri Pradini ${ }^{1}$ dan Jefri Audi Wempi ${ }^{2}$ \\ ${ }^{1,2}$ The London School of Public Relation (LSPR) Jakarta
}

\begin{abstract}
ABSTRAK
Perubahan gaya hidup, kebiasaan, dan trend dalam menikmati serta mengkonsumsi makanan pada kalangan remaja maupun dewasa, membuat para pebisnis kuliner semakin kreatif menuangkan ide-ide baru mengenai restoran, salah satunya adalah Restoran Eat Happens. Penelitian ini membahas tentang desain interior sebagai medium komunikasi nonverbal restoran Eat Happens dalam membentuk reputasi. Hal ini dilakukan dengan tujuan memahami bagaimana penggunaan desain interior untuk membentuk reputasi restoran Eat Happens. Desain interior suatu restoran diharapkan sesuai dengan konsep restoran itu sendiri agar mencerminkan identitas restoran sehingga menjadi suatu ciri khas dan membentuk reputasi yang baik di benak konsumen. Penelitian ini menggunakan teori masyarakat konsumsi dan dilengkapi dengan teori reputasi, komunikasi nonverbal dan desain interior. Metode penelitian yang digunakan adalah metode kualitatif deskriptif. Dalam penelitian ini, desain interior industrial-vintage pada restoran Eat Happens mampu menarik perhatian konsumen kemudian konsumen merasa nyaman dan percaya untuk datang mengkonsumsi produk serta suasana restoran. Selanjutnya, konsumen akan terus memberikan timbal balik yang baik kepada restoran dengan bersedia merekomendasikan kepada keluarga dan kerabatnya yang secara tidak langsung dapat membentuk reputasi restoran Eat Happens dimata masyarakat. Penggunaan desain interior dianggap menjadi penting untuk memberikan kesan pertama yang baik kepada konsumen, dan menjadi sebuah komunikasi nonverbal restoran kepada konsumen yang dapat membentuk reputasi restoran Eat Happens.
\end{abstract}

Kata-kata Kunci: Desain interior; komunikasi nonverbal; masyarakat konsumsi; reputasi; restoran eat happens

\section{ABSTRACT}

\section{Interior Design As Medium of Nonverbal Communication In Forming a Reputation at Eat Happens Restaurant}

The changing lifestyle, habits, and trends in enjoying and consuming food by teenagers and adults make culinary businesses more inventive in creating new ideas for restaurants. One example is Eat Happens Restaurant. This research is about interior design as a medium of nonverbal communication in forming a reputation at restaurant Eat Happens. The purpose is to understand how interior design can be used in forming reputation at Eat Happens restaurant. Interior design of a restaurant is to reflect the identity restaurant and form a good reputation in consumer's mind. This research uses theory of Consumer Society, Reputation Theory, Nonverbal Communication and Interior Design. The methodology research used is qualitative descriptive. In this research, industrial-vintage style interior design at Eat Happens restaurant is able to attract consumers attention and that consumers feel comfortable and confident to come and consume products and enjoy the restaurant atmosphere. Next, consumers will continue to give good feedback to restaurant and are willing to recommend to their families and friends which can form a reputation for Eat Happens restaurant among the public. The use of Interior Design is considered to be important for giving a good first impression to consumers, and becoming a restaurant nonverbal communication to consumers that can shape the reputation of Eat Happens restaurant.

Keywords: Consumer society; interior design; nonverbal communication; reputation; restaurant eat happen

Korespondensi: Rana Putri Pradini, S.I.Kom. London School of Public Relations Jakarta. J1. K.H Mas Mansyur No. Kav. 35, Jakarta Pusat 10220.Email: ranaputripradini@gmail.com 


\section{PENDAHULUAN}

Dalam usaha menciptakan sebuah reputasi restoran yang baik, ada beberapa hal yang diperhatikan oleh pemilik restoran yaitu pendapat konsumen mengenai makanan, pelayanan yang diberikan selama berada di restoran, dan juga desain interior yang menjadi bagian dari ciri khas restoran tersebut. Menurut Wicaksono \& Tisnawati, desain interior pada dasarnya terkait dengan hal merencanakan, menata dan merancang ruang-ruang interior di dalam sebuah bangunan agar menjadi sebuah tatanan fisik untuk memenuhi kebutuhan dasar manusia dalam hal penyediaan sarana bernaung dan berlindung (Wicaksono \& Tisnawati, 2014).

Perubahan gaya hidup, kebiasaan, dan trend dalam menikmati dan mengkonsumsi makanan pada kalangan remaja maupun dewasa, membuat para pebisnis kuliner semakin kreatif menuangkan ide-ide baru mengenai restoran. Desain interior suatu restoran diharapkan sesuai dengan konsep restoran itu sendiri agar mencerminkan identitas restoran sehingga menjadi suatu ciri khas dan membentuk reputasi yang baik dibenak konsumen. Suasana sebuah restoran menjadi pertimbangan terhadap minat pengunjung untuk datang ke suatu restoran tersebut, karena hal tersebut menyesuaikan dengan selera para pengunjung untuk menikmati hidangan pada sebuah restoran.
Menurut Marsum, jika suasana pada sebuah restoran dibuat menjadi sangat nyaman, maka pengunjung akan semakin tertarik untuk datang lagi ke restoran tersebut (Marsum, 2010). Setelah itu, reputasi restoran Eat Happens dapat terbentuk dibenak konsumen dan hal ini menjadi salah satu bukti adanya komunikasi nonverbal yang disampaikan restoran Eat Happens melalui desain interiornya. Selanjutnya, menurut Meldarianda \& Lisan, dalam jurnalnya yang menyatakan bahwa layout internal, tekstur dalam ruangan, serta desain interior bangunan memengaruhi minat beli konsumen. Perasaan nyaman akan membuat tamu merasa terkesan dan merindukan suasana di restoran tersebut (Meldarianda \& Lisan, 2010).

Menurut Prasetyo, suasana nyaman yang diciptakan dari desain interior restoran dapat memberikan pengalaman tersendiri bagi tamu yang datang, saat tamu tersebut pulang ke rumahnya, ia juga akan menceritakan pengalaman nya selama berada di restoran tersebut (Prasetyo, 2016). Hal inilah yang membuat desain interior sebuah restoran menjadi penting karena dapat memengaruhi pandangan seseorang dan membentuk sebuah reputasi restoran. Pernyataan tersebut juga didukung oleh penelitian dari Sukma dalam jurnalnya menyatakan bahwa suasana toko (store atmosphere) juga dapat dipahami sebagai perasaan psikologis suatu pelanggan ketika 
mengunjungi toko dan juga sekaligus sebagai identitas toko tersebut (Sukma, Fauzi, \& Yaningwati, 2012).

Restoran Eat Happens berdiri sejak tahun 2015 dan berada dibawah naungan PT. Urbie Makmur Selaras yang dikelola langsung oleh tiga saudara kandung terdiri dari Martinus Sunu Susastyo (Martin), Berto Saksono Jati (Berto), dan Theresia Alit Widyasari (Sari) berdiri sejak tahun 2003 yang juga menaungi beberapa brand yang cukup dikenal oleh remaja di Jakarta. Restoran Eat Happens membuka cabang pertamanya di Jl. Tebet Utara Dalam yang kemudian mulai ramai, dan mendapat kritikan mengenai lahan parkirnya yang kurang luas serta lahan restoran yang kurang memadai bagi jumlah pengunjung yang datang dari sekitar Jakarta maupun Bekasi. Diketahui dari laman ("Eat Happens Food Place Galaxy," 2019) restoran tersebut buka mulai pukul 16.00 WIB sampai dengan pukul 23.00 WIB. Dengan melakukan evaluasi terhadap restoran Eat Happens Tebet, maka PT. Urbie Makmur Selaras memutuskan untuk membuka cabang baru dengan lahan parkir serta lahan restoran di daerah Galaxy, Bekasi Selatan yang lebih luas dari restoran Eat Happens Tebet sebelumnya. Restoran Eat Happens Galaxy juga sukses diramaikan oleh pengunjung yang datang setiap harinya. Dengan lahan parkir dan lahan restoran yang lebih luas tersebut diharapkan dapat mengurangi jumlah pengunjung yang mengeluh karena waiting list yang terlalu banyak dan memakan waktu terlalu lama.

Restoran Eat Happens Galaxy buka mulai pukul 15.00 WIB sampai dengan pukul 23.00 WIB dengan ketentuan last order pada pukul 22.00 WIB. Namun, waiting list yang terjadi di Restoran Eat Happens Galaxy sempat mencapai titik puncaknya pada saat grand opening pada Maret 2016 yaitu sebanyak 150 antrian dengan jumlah pengunjung setiap harinya sebanyak 500 orang dan pada saat akhir pekan mencapai lebih dari 1.000 orang.

Beberapa customer yang merasakan antrian panjang tersebut, merasa tidak masalah untuk menunggu dan menolak pada saat pelayan atau manajer restoran menyarankan untuk take away makanan yang akan mereka pesan. Hal tersebut terjadi karena mereka tetap ingin menikmati dan mengkonsumsi makanannya ditempatnya langsung karena mereka ingin merasakan suasana dari desain interior yang ada di Eat Happens Galaxy. Hal ini sejalan dengan penelitian yang dilakukan oleh (Anggraeni \& Hermiati, 2013), dimana saat ini suasana toko (store atmosphere) dari suatu restoran dapat dijadikan alasan oleh konsumen untuk berada lebih lama dalam suatu restoran. Berdasarkan hal tersebut, restoran Eat Happens Galaxy terus berkomitmen untuk membuat suasana restoran tetap nyaman, serta menjaga pelayanan dan 
kualitas makanan yang baik. Karena selain desain interiornya yang dibuat menarik dengan tujuan untuk mendukung restoran Eat Happens dalam membentuk sebuah reputasi dimata konsumen, menu makanannya yang hits juga menjadi ciri khas dengan berbagai macam menu yang sedang terkini (happening) sesuai dengan bagian belakang nama restoran nya.

Berdasarkan review dari beberapa customer restoran Eat Happens di laman zomato mengatakan, desain interior restoran Eat Happens sangat unik, dan kekinian dengan menggunakan barang-barang recycle seperti container yang dijadikan dinding dan pintu geser, drum sebagai kursi, meja yang berbentuk mesin jahit, serta kursi bar yang dilengkapi rantai sepedah beserta pedalnya dan dinding yang setengah jadi (konsep industrial), quotesquotes hipster di dinding restoran, warmlighting, dan simbol-simbol yang menjadi bagian pemanis dalam interior restoran Eat Happens. Tidak sedikit customer yang datang tanpa selfie dan update di media sosial dan menandai akun sosial media milik restoran Eat Happens. Quotes-quotes serta pencahayaan yang baik membuat pengunjung yang datang tertarik untuk mengambil gambar dari beberapa bagian desain interior yang terdapat didalam restoran tersebut.

Salah satu hal yang juga membuat restoran tersebut semakin dikenal oleh kalangan remaja di Jakarta maupun Bekasi adalah berdasarkan review dan rekomendasi dari teman-teman mereka sendiri, keluarga, review beberapa artis muda, testimonial melalui akun Facebook, followers di Instagram, Twitter, serta review di laman zomato. Dalam testimonial dan review yang disampaikan oleh konsumen bukan hanya membahas mengenai makanan dan pelayanannya saja, namun juga membahas konsep desain interior dan suasana dari restoran Eat Happens tersebut yang menjadi suatu daya tarik untuk disampaikan juga kepada konsumen lainnya.

Rekomendasi dari konsumen tersebut akan menjadi suatu kegiatan promosi yang efektif dan positif dimata publik yang akan membentuk reputasi restoran yang baik dari konsumen kepada konsumen lainnya. Dimana menurut Kotler \& Keller konsumen yang melakukan kegiatan positive word of mouth berperan sebagai opinion leader bagi konsumen lainnya (Kotler \& Keller, 2012). Hal ini efektif bagi bisnis kecil yang bergerak dibidang kuliner, dimana restoran dapat memiliki hubungan yang lebih personal dengan konsumennya melalui review yang diberikan oleh konsumen kepada restorannya. Instagram restoran Eat Happens memiliki 23.200 followers. Menurut Tresnawati \& Prasetyo yang menyatakan bahwa fungsi sesungguhnya dari Instagram adalah sebagai salah satu media untuk memproduksi foto dan 
berbagi dalam waktu yang sangat cepat, namun saat ini Instagram juga semakin bertambah fungsinya menjadi wadah para pebisnis untuk memasarkan produk dan jasanya (Tresnawati \& Prasetyo, 2018). Pernyataan tersebut juga didukung oleh penelitian menurut Ayutiani, Primadani, \& Putri yang menyatakan bahwa dengan kemudahan cara penggunaan aplikasi Instagram membuat pengguna menjadikan Instagram sebagai media informasi untuk memenuhi kebutuhannya termasuk untuk mencari informasi rekomendasi wisata kuliner Produk online shop yang dikomunikasikan melalui Instagram mulai dari fashion, hingga kuliner (Ayutiani, Primadani, \& Putri, 2018). Review dalam laman Zomato (2016) mengenai Eat Happens Tebet tercatat sebanyak 414 Reviews dan 533 votes dengan rating 3.8/5. Review Eat Happens Galaxy tercatat sebanyak 64 Reviews dan 71 votes dengan rating 3.6/5 dengan kesimpulan baik.

Berdasarkan latar belakang, maka permasalahan dalam penelitian ini adalah Bagaimana Desain Interior Sebagai Medium Komunikasi Nonverbal Restoran Eat Happens Dapat Membentuk Reputasi?

Adapun tujuan dari penelitian ini adalah untuk memahami bagaimana penggunaan desain interior untuk membentuk reputasi restoran Eat Happens.

Menurut Baudrillard masyarakat konsumsi menunjukkan gejala konsumerisme yang sangat luar biasa dan telah menjadi bagian dari gaya hidup manusia modern (Baudrillard, 2010). Objek konsumsi tidak hanya berbentuk barang, namun lebih dari itu. Agar sebuah objek dapat menjadi konsumsi, objek tersebut harus mengandung tanda makna atau simbol-simbol (Symbolic and value exchange) yang dapat mendukung identitas diri seseorang. Karena manusia masa kini mengkonsumsi barang bukan berdasarkan kebutuhan atau nilai guna suatu barang, melainkan untuk memuaskan hasrat dan mendapatkan kesetaraan sosial dimata masyarakat lainnya.

Penampilan suatu objek yang berbeda dengan yang lain dianggap lebih penting karena objek tersebut dapat membentuk citra diri seseorang dan menggambarkan reputasi dirinya. Sebagai contoh, banyak orang yang lebih memilih membeli “merek” atau objek yang ramai dibicarakan dari mulut ke mulut maupun sosial media karena objek tersebut memiliki reputasi yang baik sekaligus membawa status bagi orang yang mengkonsumsinya.

Dapat dikatakan orang lebih senang berkumpul bersama teman-temannya di sebuah restoran terkenal daripada di warung pinggir jalan. Selain memilih tempat untuk berkumpul, kebanyakan orang juga memilih tempat yang unik dan terkenal dengan alasan untuk di unggah ke media sosial dan dipamerkan 
kepada teman-teman lainnya. Hal tersebutlah yang dimaksudkan Baudrillard bahwa orang sekarang lebih gemar mengkonsumsi 'tanda' yang memiliki arti dan makna sosial bagi dirinya dan orang-orang disekitarnya. Bila pada awalnya konsumsi dimaknai sebagai proses pemenuhan kebutuhan, maka kini konsumsi dialih fungsikan sebagai sarana mengekspresikan posisi dan identitas seseorang dimata masyarakat (Purwanto, 2011).

Sebagai contoh, ketika orang membeli makan, dimana makan merupakan kebutuhan pokok yang harus terpenuhi, maka orang tersebut kini juga memikirkan untuk memilih makanan dengan tempat yang bersih dan nyaman, serta mengutamakan tata cara maupun gaya dari penampilan dan penyajian makanan itu sendiri. Sehingga, gaya makan dan suasana pendukung untuk makan kini lebih diutamakan dibandingkan dengan fungsi utama dari makan itu sendiri.

Baudrillard menjelaskan bahwa perilaku konsumsi saat ini tidak hanya dipengaruhi oleh faktor-faktor yang murni ekonomis tetapi juga terdapat sistem budaya atau sistem pemaknaan sosial sehingga mampu mengarahkan seorang individu (Baudrillard, 2010). Nilai tanda yang dikonsumsi oleh seorang individu dalam masyarakat konsumsi berupa status, prestige, ekspresi dan lain-lain. Pandangan Baudrillard menjelaskan bagaimana struktur komunikasi dan sistem tanda mampu mempertahankan eksistensi masyarakat konsumen tersebut. Simbolisasi dalam masyarakat konsumsi saat ini mengkonstruksi identitasnya, sehingga gaya hidup bisa mencitrakan keberadaan seseorang pada suatu status sosial tertentu.

Kegiatan public relations pada dasarnya merupakan suatu kegiatan yang terencana dan secara terus menerus bertujuan untuk dapat mengembangkan itikad baik dan menciptakan pengertian yang timbal balik (mutual understanding) antara suatu organisasi dengan masyarakat. Alat yang sering digunakan untuk menunjang marketing dan target suatu bisnis disebut "Marketing Public Relations". Staf PR yang bekerja di bidang ini biasanya menurut Wilcox, et al. tergabung dalam divisi marketing (Ardianto, 2007). Pada era globalisasi ini peran marketing public relations menjadi semakin penting karena pembentukan simpati konsumen secara efektif dan efisien.

Menurut Thomas L. Haris bahwa marketing public relations adalah proses dari perencanaan, pelaksanaan, dan evaluasi program-program yang mendorong pembelian serta kepuasan konsumen melalui komunikasi informasi dan kesan yang dapat dipercaya, yang mengidentifikasikan organisasi atau perusahaan dan produknya dengan kebutuhan, keinginankeinginan, konsentrasi dan ketertarikan dari konsumen (Ardianto, 2011). 
Berdasarkan definisi tersebut, Marketing Public Relations (MPR) penekanannya lebih kepada pemberian informasi, dan upaya peningkatan pemahaman melalui pengetahuan mengenai suatu merek produk ataupun jasa, yang nantinya akan berdampak kuat bagi perusahaan dan lebih lama diingat oleh konsumen. Dengan tingkat komunikasi yang lebih intensif bila dibandingkan dengan iklan, Haris menyatakan bahwa MPR merupakan suatu konsep yang lebih tinggi diatasnya (Ardianto, 2011). Menurut Fombrun seperti yang dikutip oleh (Ardianto, 2014) mengenai reputasi dimulai dari identitas korporat sebagai titik pertama yang tercermin melalui nama perusahaan $(\log 0)$, dan tampilan lainnya seperti kemasan produk, interior kantor, pemberitaaan media serta yang berupa non fisik, seperti dan komunikasi baik internal perusahaan maupun pihak luar. Reputasi menjadi baik atau buruk, kuat atau lemah bergantung pada komitmen manajemen untuk mencapai tujuan yang telah ditetapkan, serta adanya keterampilan untuk mengkomunikasikan nya.

Dalam sebuah perusahaan, orang-orang yang berperan dalam kegiatan Public Relations (PR) diharapkan mampu menggunakan komunikasi yang efektif dalam rangka menyesuaikan tugasnya dalam perusahaan tersebut. Oleh karena itu, sering dikatakan bahwa perencanaan komunikasi merupakan satu langkah penting dan strategis dalam PR.

Reputasi adalah penilaian yang diberikan, baik oleh pihak internal maupun pihak eksternal perusahaan. Pihak internal sebuah perusahaan merupakan wujud dari identitas. Semakin baik kinerja dan kualitas diri internal, semakin baik identitas perusahaan di mata publik. Jadi, reputasi merupakan perpaduan antara identitas dan citra yang sudah dibangun. Selain itu, reputasi juga berkaitan dengan kepercayaan yang mahal harganya. Dengan komunikasi, maka PR akan dapat memelihara publik dan khalayaknya agar tetap setia pada produk yang dibuat oleh perusahaannya (Hamid \& Budianto, 2011). Dengan demikian, reputasi dan citra positif suatu perusahaan akan terpelihara, bahkan dapat semakin meningkat.

Komunikasi nonverbal menurut Mulyana, didefinisikan sebagai suatu pesan yang memiliki makna tertentu dibalik proses penyampaian pesan tersebut (Mulyana \& Rakhmat, 2005). Makna tersebut dapat terlihat hanya dengan melihat ekspresi yang ditampilkan seseorang, makna tersebut juga dapat tersirat melalui simbol-simbol ataupun desain interior yang ditampilkan pada suatu restoran, yang nantinya akan membawa orang lain yang melihatnya menjadi memiliki suatu persepsi yang sama sesuai dengan apa yang ingin di sampaikan oleh pemilik restoran tersebut.

Secara sederhana, pesan nonverbal adalah 
semua isyarat yang bukan kata-kata. Menurut Larry A. Samovar dan Richard E. Porter, komunikasi nonverbal mencakup semua rangsangan (kecuali rangsangan verbal) dalam suatu setting komunikasi, yang dihasilkan oleh individu, yang mempunyai nilai pesan potensial bagi pengirim atau penerima (Mulyana \& Rakhmat, 2005).

Menurut AndieA. Wicaksono dan Tisnawati desain interior pada dasarnya terkait dengan hal merencanakan, menata dan merancang ruang-ruang interior di dalam sebuah bangunan agar menjadi sebuah tatanan fisik untuk memenuhi kebutuhan dasar manusia dalam hal penyediaan sarana bernaung dan berlindung (Wicaksono \& Tisnawati, 2014). Sebuah desain interior dapat memengaruhi pandangan, suasana hati seseorang yang melihatnya. Oleh sebab itu, tujuan perancangan interior sebagai pengembangan fungsi, pengayaan estetis dan peningkatan psikologi ruang interior.

\section{METODE PENELITIAN}

Metode penelitian yang digunakan dalam penelitian ini adalah metode deskriptif kualitatif. Creswell, mengatakan bahwa ciri dari penelitian deskriptif kualitatif ialah menitikberatkan pada observasi dan suasana alamiah. Peneliti terjun langsung ke lapangan untuk mengamati gejala yang ada dan mencatatnya dalam buku observasi (Creswell, 2014). Tujuan yang diharapkan dari penggunaan metode penelitian deskriptif kualitatif adalah agar informasi mengenai desain interior sebagai medium komunikasi nonverbal restoran Eat Happens dalam membentuk reputasi didapat secara lengkap.

Narasumber internal pada penelitian ini adalah pemilik sekaligus pendiri restoran Eat Happens, seorang Public Relations PT. Urbie Makmur Selaras yang menjalankan fungsi Marketing Public Relations dalam publikasi dan mengurus manajemen reputasi restoran Eat Happens, dan internal interior designer yang menangani langsung desain interior restoran Eat Happens. Sedangkan untuk narasumber eksternal pada penelitian ini adalah interior designer Line Up Studio Desain dan 20 orang konsumen restoran Eat Happens dengan ketentuan konsumen yang menjadi narasumber sesuai dengan usia target pasar restoran Eat Happens, serta memahami dan menyukai desain interior restoran.

Dalam menganalisa data, diperlukan 2 jenis data untuk mendukung penelitian yaitu data primer dan data sekunder. Data primer adalah data yang dikumpulkan peneliti langsung dari sumber utamanya. Data ini digunakan karena tidak semua informasi dapat diperoleh dari data sekunder, maka jika tidak tersedia informasi dari data sekunder diperlukan usaha untuk memperoleh dari sumber utama yang merupakan data primer. 
Data sekunder adalah data yang bersumber dari hasil penelitian orang lain yang dibuat untuk maksud yang berbeda. Data tersebut dapat berupa fakta, tabel, gambar, dan lain-lain. Data sekunder dibutuhkan sebagai pelengkap data primer agar seluruh data dapat menjadi informasi yang berarti (Kountur, 2007). Metode atau teknik pengumpulan data yang peneliti lakukan adalah melalui wawancara mendalam.

Wawancara mendalam merupakan teknik pengumpulan data atau informasi dengan cara bertatap muka secara langsung dengan informan agar mendapati data yang lengkap dan mendalam (Ardianto, 2014). Wawancara ini lebih memfokuskan pada persoalan-persoalan yang menjadi pokok dari minat penelitian. Wawancara ini akan dilakukan dengan cara menemui langsung narasumber atau informan yang sebelumnya telah membuat perjanjian waktu wawancara dengan peneliti. Peneliti akan merekam hasil percakapan yang kemudian akan dibuat transkripnya dalam bentuk tulisan.

Teknik analisis yang diterapkan dalam penelitian iniadalah teknik analisis datakualitatif yang dikembangkan oleh (Miles, Huberman, \& Saldana, 2015) mengungkapkan bahwa analisis data dalam kualitatif berkesinambungan dan merupakan 3 aktivitas yang bersamaan. Tiga aktivitas tersebut adalah kondensasi data, tampilan data, serta penarikan dan verifikasi kesimpulan
Sehingga, dalam penelitian ini dapat diuraikan bahwa peneliti menyortir seluruh data yang telah diperoleh dan di kumpulkan dari berbagai sumber agar terpilih data yang paling sesuai dengan topik yang diteliti. Setelah semua data terkumpul, peneliti akan menarik kesimpulan secara garis besarnya. Pada tahap ini peneliti akan mengetahui hubungan antara desain interior restoran Eat Happens dengan pembentukan reputasi.

Triangulasi dalam teknik pemeriksaan kepercayaan ini diartikan sebagai pengecekan data dari berbagai sumber dengan berbagai cara, dan berbagai waktu (Sugiyono, 2015). Peneliti menggunakan triangulasi data untuk mengetahui keabsahan data. Menurut Sugiyono, triangulasi terbagi menjadi 3 yaitu Triangulasi Sumber, Triangulasi Teknik, dan Triangulasi Waktu. Dalam penelitian ini, peneliti menggunakan teknik triangulasi sumber, dimana triangulasi sumber dilakukan untuk menguji kredibilitas data dengan cara mengecek data yang telah diperoleh melalui beberapa sumber. Data yang telah di analisis oleh peneliti menghasilkan suatu kesimpulan, yang selanjutnya akan dilakukan kesepakatan dalam proses pengecekan data tersebut yang telah diperoleh peneliti kepada pemberi data untuk menguji keabsahan data. Sehingga data yang diperoleh dapat di periksa kembali dan diketahui persamaan, perbedaan, dan juga yang 
menjadi bagian inti dari keseluruhan data yang diterima peneliti dari seluruh narasumber.

\section{HASIL DAN PEMBAHASAN}

Eat Happens dibentuk dari kata Eat dan Happens. Eat yang berarti makan, dan Happens yaitu happening/terkini. Pemilik restoran Eat Happens menyebutnya sebagai makanan kekinian, dengan kata Eat Happens maka setiap orang yang mendengarnya dapat dengan mudah menyimpulkan sendiri ketika mendengar nama tersebut, serta mudah untuk dihafal sehingga lebih familiar bagi orang-orang disekitarnya. Hal ini senada dengan pernyataan dari(Eddyono, 2011) tagline yang kreatif, agar memudahkan publik untuk mengingat

Eat Happens memang sengaja dibuat untuk menciptakan sebuah trend dari makanan yang sedang terkini (happening). Berbagai macam menu mulai dari menu tradisional sampai menu siap saji ada di restoran tersebut dan disajikan dengan tampilan yang menarik dan unik. Desain Interior nya juga menarik perhatian bagi anakanak remaja yang sebagian besar menjadi target pasarnya.

Restoran Eat Happens membuat property dan desain interior menarik sebagai suatu pendukung penyajian/display pada makanan maupun interior restoran hingga dapat menjadi suatu symbol exchange yang pada masa ini banyak dicari oleh anak muda, dimana saat ini konsumen datang ke suatu restoran tidak hanya untuk sekedar makan lalu pulang tanpa merasakan sesuatu hal berbeda dari tempat makan satu ke tempat makan lainnya. Restoran Eat Happens memahami kebutuhan konsumen yang menyukai suatu hal menarik dan up-to-date untuk dijadikan objek foto juga tempat berkumpul bersama kerabat atau keluarga nya dalam waktu yang lama hingga mendapat pengakuan khusus dari orang-orang disekitarnya.

Restoran Eat Happens memiliki 4 booth, terdiri dari booth khusus Makanan, Minuman, Cendol \& Duren Bar dan Martabak Happens yang didukung dengan display menarik serta eyecatching sehingga membuat konsumen nya merasa penasaran hingga ingin mencicipi menu yang ada di setiap booth nya. Diantaranya, booth yang memiliki display menarik di restoran Eat Happens adalah 2 booth yang terletak pada lantai 1 bagian luar ruangan restoran. Terdapat booth Martabak Happens yang di dekorasi menggunakan mobil biasa namun di modifikasi hingga menyerupai mobil van sungguhan, hal tersebut ditujukan untuk menciptakan kesan antik juga unik yang mendukung dan menyempurnakan konsep vintage dari restoran Eat Happens tersebut. Seperti yang dikatakan oleh Saipul Bahri selaku desainer interior restoran Eat Happens, warna kuning dari lampu yang digunakan merefleksikan kesan hangat dan 


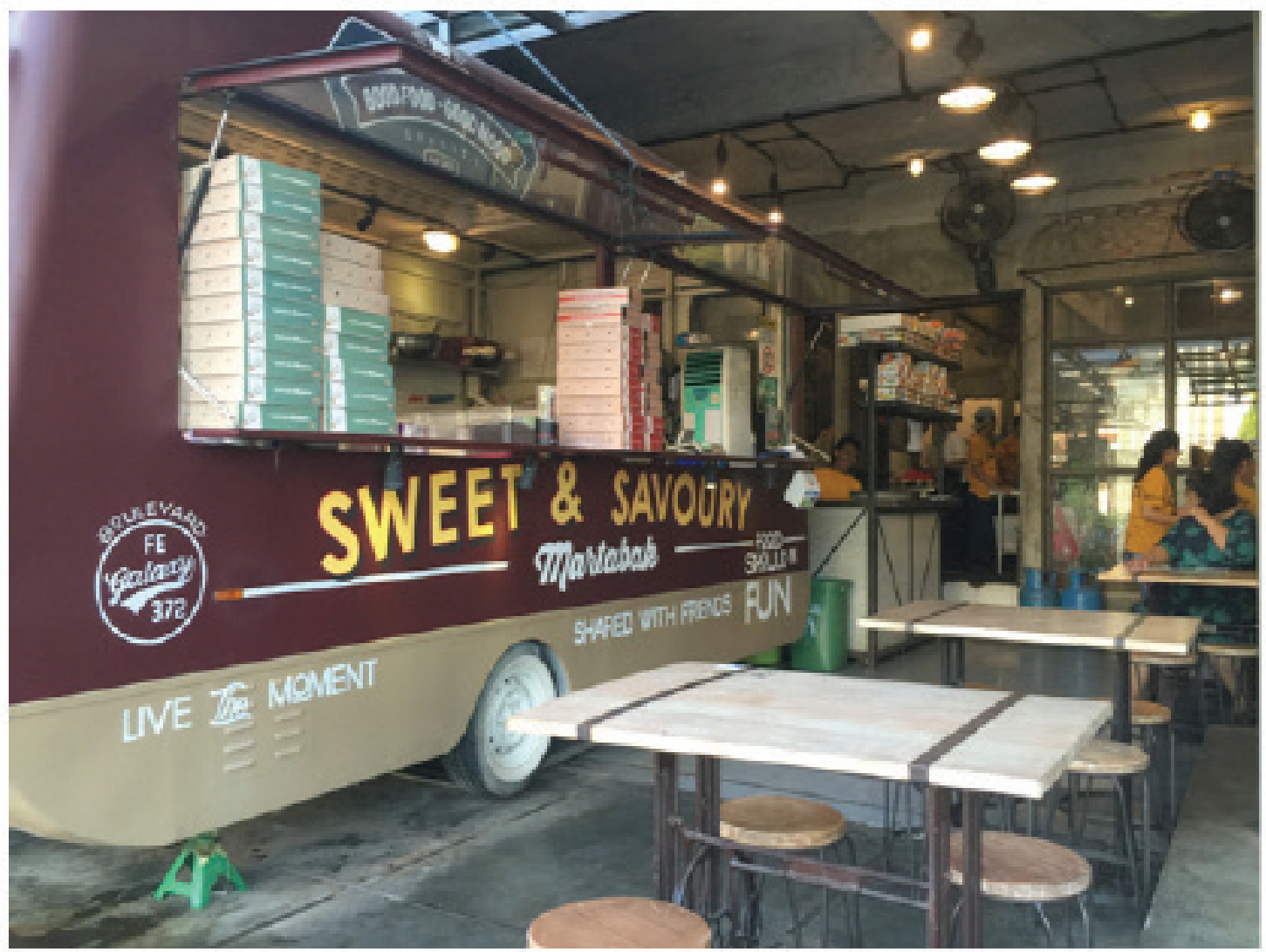

Sumber: Dokumen Pribadi Rana Putri Pradini, 2017

\section{Gambar 1 Desain Booth Restoran Eat Happens}

nyaman serta mendukung desain interiornya.

Booth ini terletak pada bagian depan bangunan untuk menunjukkan identitas dari restoran Eat Happens sebagai menu andalan yang menjadi ciri khas restoran Eat Happens.

Pada sisi bagian lain luar ruangan restoran Eat Happens juga terdapat booth Cendol \& Duren Bar dengan warna biru muda. Display dari booth ini banyak menggunakan efek komik, sehingga nuansa vintage pada booth tersebut lebih terlihat, hal tersebut bertujuan untuk menarik perhatian konsumen sehingga terlihat lebih berwarna dan eyecatching. Hasil penelitian (Sukma et al., 2012) menemukan bahwa emosi memiliki pengaruh signifikan terhadap struktur keputusan pembelian. Lebih lanjut, menurut pemilik restoran Eat Happens, Bapak Martinus yang menyatakan mengenai alasan dan tujuan dari dibedakan nya desain dari setiap booth yang ada, yaitu untuk mendapatkan daya tarik dari setiap konsumen yang datang "tujuannya adalah membedakan restoran kami dengan restoran lainnya, terkesan tidak umum dan mendapatkan daya tarik yang unik juga"

Menurut tanggapan yang disampaikan oleh Martinus Sunu Susastyo selaku pemilik Restoran Eat Happens mengenai konsep dari restoran tersebut adalah:

"Konsep kami adalah industrial-vintage, 


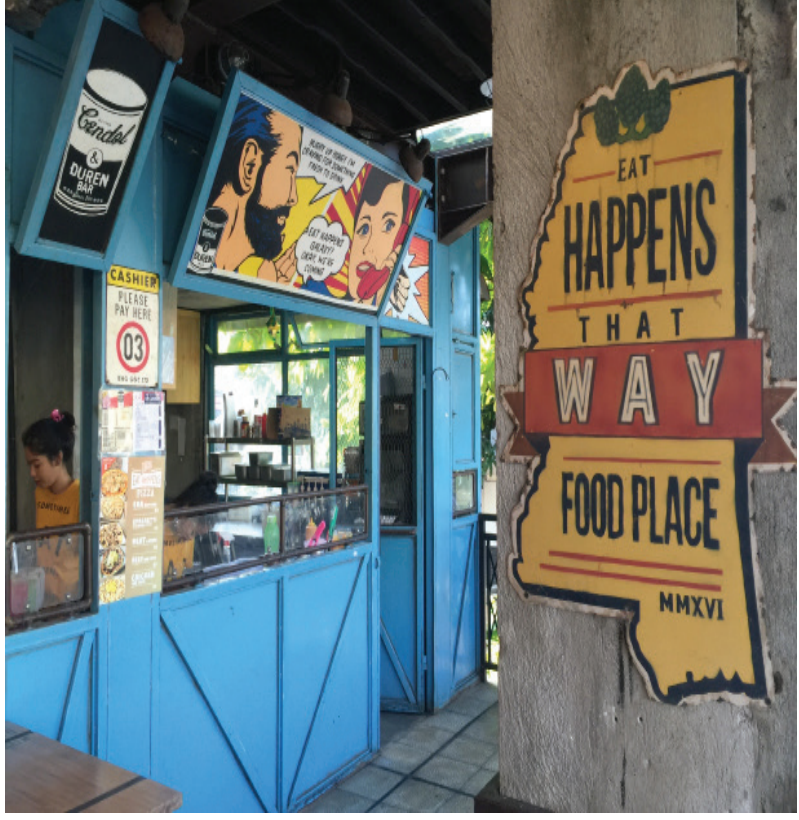

Sumber: Dokumen Pribadi Rana Putri Pradini, 2017

Gambar 2 Desain Booth Restoran Eat Happens

kami menginginkan semua barangbarang yang digunakan adalah raw dan memanfaatkan kembali semua barangbarang yang sudah tidak terpakai, sehingga menimbulkan kesan bahwa sesuatu yang artistic itu tidak harus mahal atau modern. Jadi, kami ingin menonjolkan tema retro vintage, seperti itu"

Berdasarkan tanggapan tersebut, diketahui bahwa restoran Eat Happens juga memanfaatkan barang-barang yang sudah tidak terpakai sebelumnya, kemudian dimodifikasi untuk mendukung desain interior sehingga dapat menarik perhatian konsumen. Restoran Eat Happens berinovasi dengan property yang dipakainya, sehingga bisa menjadi ciri khas dan keunikan tersendiri dimata konsumen. Adanya desain interior ini juga ditujukan untuk membentuk suatu identitas dan reputasi restoran.

"Pastinya juga untuk membentuk identitas dan reputasi ya, sehingga pada saat nanti

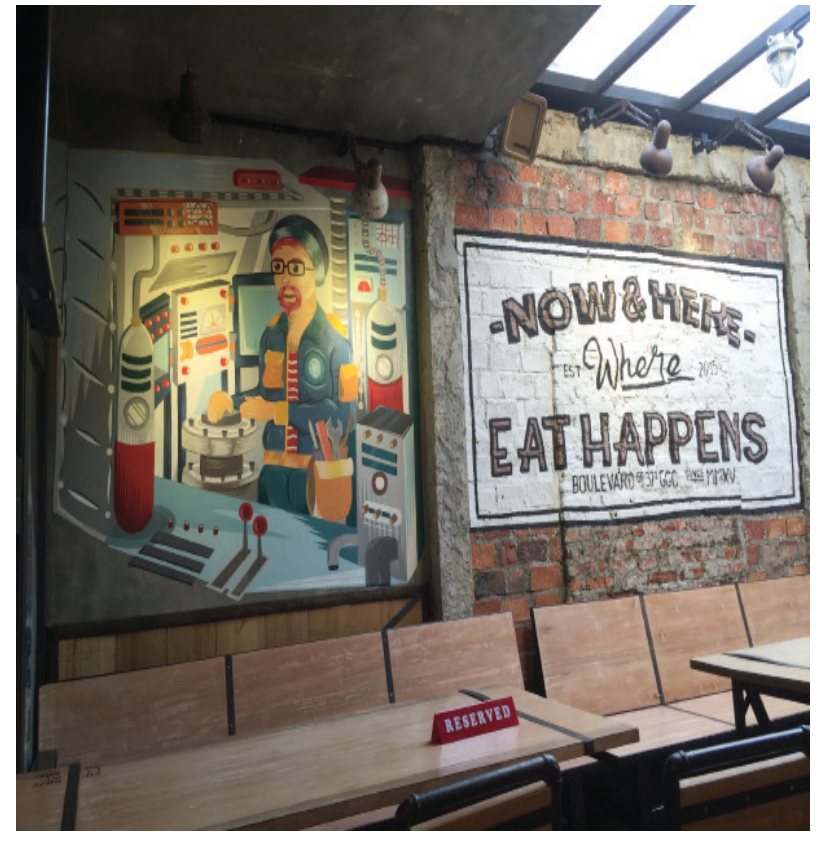

Sumber: Dokumen Pribadi Rana Putri Pradini, 2017

Gambar 3 Desain Interior Restoran Eat Happens

ada konsumen baru yang datang ke Eat Happens, dia sudah dapat merasakan bahwa Eat Happens ya memang seperti ini, orang sudah pada tahu...kami juga menggunakan beberapa property yang unik untuk menambah art desain interiornya"

Desain interior restoran tersebut memang banyak memanfaatkan kembali barang-barang yang sudah tidak terpakai dan di modifikasi sehingga menciptakan sesuatu yang lebih artistik jika dilihat dari segi konsep industrialis nya, sedangkan untuk menunjang konsep vintage nya, restoran ini juga tidak memilih untuk menghabiskan banyak biaya dengan membawa property vintage yang sungguhan, pemilik restoran Eat Happens lebih memilih untuk membuat sendiri dan mendesain sendiri sign-sign yang di gunakan dalam property desain vintage nya berdasarkan referensi restoran-restoran yang berada di luar negeri, 
sehingga restoran Eat Happens tetap memiliki ciri khas yang menjadi identitas dan perbedaan yang unik jika dibandingkan dengan restoranrestoran di sekitarnya.

Menurut beberapa konsumen, desain interior restoran adalah salah satu hal utama yang mereka perhatikan sebelum memutuskan untuk mengunjungi suatu restoran. Selain menjadi daya tarik tersendiri, desain interior juga berpengaruh kepada mood bagi dirinya sendiri untuk menikmati suatu makanan, konsumen juga menyempatkan diri untuk mengabadikan momen bagi dirinya sendiri ataupun bersama kerabat dan keluarga, untuk diunggah ke sosial media. Salah satunya adalah Nasta, salah satu konsumen yang bekerja di TV One, Nisrin Nur Aisyah dan Fransiskus Xaverius Dwi Arianto Nugroho mahasiswa universitas swasta di Jakarta.

"...hari gini kalau ada cafe yang interiornya unik kan lebih eyecatching gitu, apalagi kalau instagrammable ya, biasanya akan ramai sama anak-anak muda" (Wawancara Nasta, 2017).

"...yang dilihat pertama kali pasti desain nya ya. Kalau soal makanan biasanya itu nomer dua atau nomer tiga lah ya, karena kan pasti ditinjau dari apa yang terlihat oleh mata terlebih dahulu" (Wawancara Nisrin, 2017).

"kalau kita makan di restoran tapi desain interiornya nggak bagus, memengaruhi mood juga nantinya" (Wawancara Fransiskus, 2017).
Terdapat pintu container yang membatasi ruang makan outdoor pada booth Martabak dengan ruang makan yang berdekatan dengan pintu masuk utama dan booth Cendol \& Duren Bar. Pintu tersebut biasa dimanfaatkan juga sebagai spot foto bagi anak-anak muda karena penepatan nya yang unik dan konsepnya yang industrialis didukung dengan tembok yang setengah jadi dan lampu-lampu yang dihiasi dengan pipa-pipa semi pabrik.

Pintu bekas kontainer lainnya juga diletakan pada bagian tembok pembatas outdoor dengan indoor pintu utama, dengan warna cokelat menyesuaikan dengan desain interior nya yang mendominasi warna kuning kecokelatan. Pada sisi kanan pintu utama, terdapat lukisan mascot restoran Eat Happens yang sedang memakai baju astronot dengan tangan melambai keatas menandakan pemilik restoran Eat Happens mengucapkan selamat datang di restoran Eat Happens Galaxy yang bertemakan galaxy luar angkasa namun tetap dengan konsepnya vintage-industrialis.

Menurut Ridhwan, Interior designer Line Up Studio yang juga mengamati restoran Eat Happens, menurutnya dinding-dinding pada plafon restoran sengaja dibuka sehingga menampilkan bata expose dan beton serta pada bagian lampunya ditutupi kerangka besi dan instalasi pipa. Hal tersebut ditujukan untuk mendukung konsep industrial nya. 


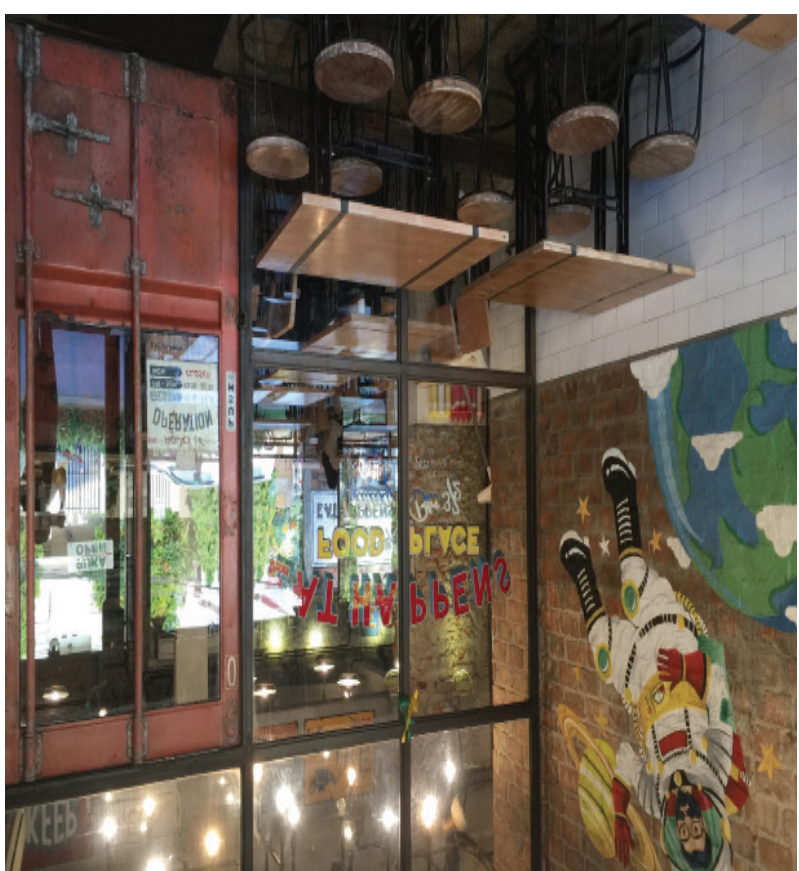

Sumber: Dokumen Pribadi Rana Putri Pradini, 2017

\section{Gambar 4 Pintu Container Restoran Eat Happens}

Menurut Saipul Bahri selaku desainer interior restoran Eat happens, alasan restoran Eat Happens mengaplikasikan dinding yang setengah jadi yaitu,

"Karena pada umumnya restoran dibangun dengan rapih, dan di cat sedemikian rupa, berbeda dengan pemikiran kami bahwa jika suatu restoran dibuat setengah jadi akan menjadi lebih unik. Walaupun mungkin beberapa konsumen ada yang berpendapat beda dengan apa yang kami maksud"

Dengan membuat restoran terlihat lebih unik, akan ada banyak konsumen yang datang dan rela mengantri untuk merasakan suasana restoran tersebut, juga mencicipi makanan yang dianggap happening saat itu. Hal ini didukung dengan pernyataan salah satu konsumen yang bernama Wahyu Ferida Wulandari mengenai pendapatnya terhadap desain interior restoran
Eat Happens,

"Menurut saya restoran Eat Happens itu unik, menarik, dan anak muda banget. Kebetulan juga saya sudah 5 kali kesini dan biasanya selalu waiting list dan rela nungguin karena suka banget kesini"

Wulan juga mengatakan bahwa desain interior suatu restoran menjadi daya tariknya untuk mengunjungi restoran karena menurutnya anak muda zaman sekarang ketika mencari restoran, dilihat juga dari keunikan interiornya, yang unik untuk foto-foto dan di unggah ke sosial media.

Untuk mendukung desain interiornya, restoran Eat Happens menggunakan property pendukung yang tidak biasa bagi konsumennya. Meja makan yang dipakai pada bagian outdoor maupun indoor menggunakan meja kayu yang di konsepkan berbentuk mesin jahit, dimana terdapat pedal untuk mengayunkan kaki seperti sedang menjahit. Kursi bar pada bagian booth minuman atau bartender juga sengaja dibuat dengan penambahan pedal sepedah lengkap dengan rantai nya, hal tersebut ditujukan untuk menambah kenyamanan konsumen nya. Seperti yang diungkapkan oleh Ulfa Damayanti yang sudah pernah merasakan makan di atas meja yang menyerupai mesin jahit

"Bagus ya, unik. Pada bagian meja makannya juga terdapat pedal mesin jahit ya, jadi kaki kita bisa iseng gerak-gerak seolah lagi 


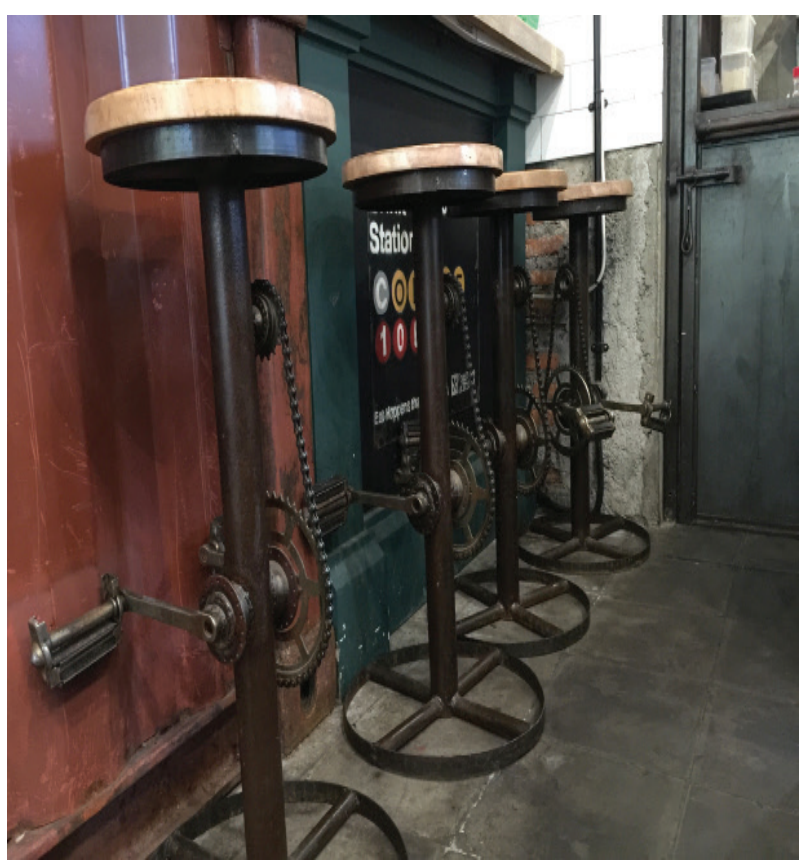

Sumber: Dokumen Pribadi Rana Putri Pradini, 2017

\section{Gambar 5 Kursi Bar Restoran Eat Happens}

menjahit. Lucu sih, menambah kenyamanan juga"

Pemilik restoran Eat Happens juga banyak menempatkan berbagai macam mural dan lukisan yang bertemakan galaxy dan dipadukan dengan quotes yang menggambarkan kehidupan anak muda pada zaman ini. Dimana pada era post-modern ini, kemajuan teknologi membuat anak muda mengutamakan media digital sebagai media komunikasi kepada kerabat maupun keluarga, termasuk juga dalam mencari tahu sebuah berita terkini. Restoran Eat Happens sadar akan hal tersebut, hingga mereka menempatkan mural menyesuaikan dengan situasi dan kondisi pada era ini, sehingga pesan mereka sampai dibenak konsumen yang menjadi target pasar mereka.

Restoran Eat Happens ingin membuat konsumen merasa nyaman dan mencoba mengerti kebutuhan para konsumen nya yang membutuhkan tempat untuk merelaksasi diri, dan terhibur dengan suasana dan dekorasi dari desain interior restoran Eat Happens.

Desain interiornya selain bisa dijadikan spot untuk foto-foto, juga bisa dijadikan sebuah humor bagi konsumen ataupun pengunjung yang tersentuh dengan pesan dan makna dari quotes nya.

Kata 'study' pada salah satu mural pada ruang makan bagian dalam lantai 1 bermaksud menjelaskan arti dari kata tersebut, namun apa yang di artikan bukanlah arti yang sebenarnya melainkan humor yang menghibur bagi setiap orang yang membacanya. Dalam mural tersebut, kata 'Study' diartikan sebagai salah satu aktivitas memainkan handphone sambil menikmati makanan dan juga menonton

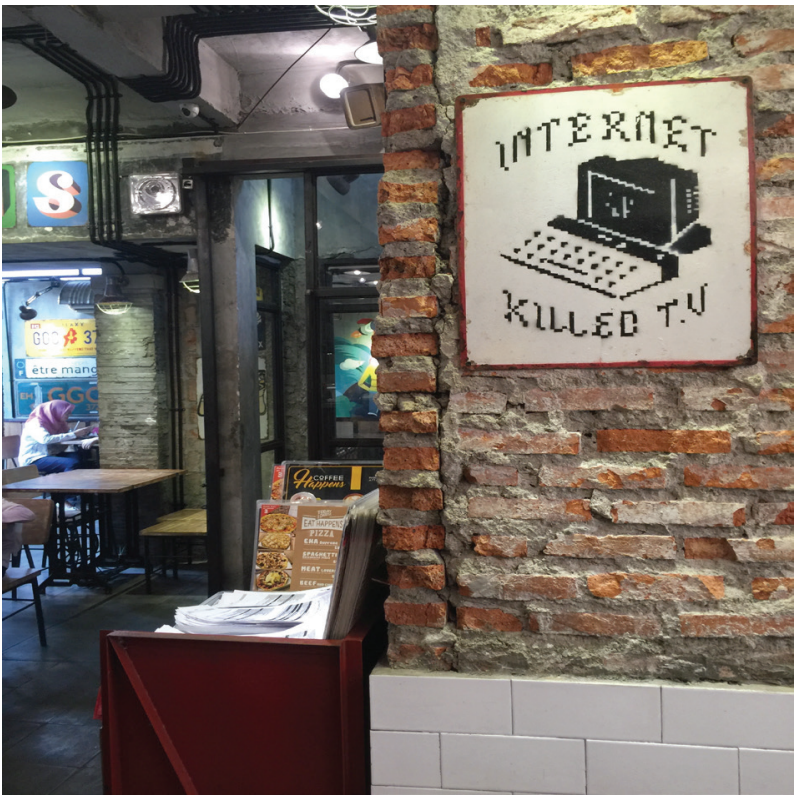

Sumber: Dokumen Pribadi Rana Putri Pradini, 2017

Gambar 6 Mural Dekorasi Restoran Eat Happens 
televisi dengan dikelilingi buku-buku pelajaran yang terbuka untuk sekedar di update di sosial media. Jika disimpulkan. Restoran ini ingin menyampaikan situasi yang terjadi pada anak remaja masa kini, belajar namun tetap sibuk dengan aktivitasnya didunia maya.

Diketahui bahwa mural dengan quotes 'Chillin, Need to Relax' di adaptasi dan dimodifikasi dari salah satu logo terkemuka yaitu Michelin. Sedangkan mural yang menggambarkan karakter tokoh kung-fu yang di modifikasi hingga terlihat seperti sedang memotret menggunakan kamera handphone nya, sehingga diberikan quotes 'Selfie' sesuai dengan pose nya.

Adanya mural tersebut bukan tanpa alasan, mural tersebut dapat mengasah kemampuan menganalisa sebuah logo bagi seseorang yang melihatnya, kemudian akan memberikan hiburan tersendiri dan juga mengasah kreativitas bagi mereka yang mengerti maksud dari muralmural tersebut. Didukung dengan pernyataan dari Saipul Bahri, desainer interior restoran Eat Happens yang menyatakan;

"Kami ingin menampilkan suatu quotes yang berbeda atau eye catching, tidak lagi quotes yang terlalu klise dan umum, melainkan quotes yang diaplikasikan dengan logo-logo yang umumnya dikenal oleh masyarakat, namun kami modifikasi dengan isu-isu yang sedang booming tentang kehidupan remaja saat ini”

Dalam menyempurnakan konsep vintageindustrialis, pemilik restoran Eat Happens tidak hanya mendekor ruang makan nya saja tetapi juga pada bagian toilet dan tangga restoran tersebut. Mulai dari menggunakan pipa-pipa dan tanki bensin buatan hingga ban yang dijadikan wastafel pada toilet nya yang dihiasi dengan penambahan mural bergambar roket luar angkasa dan dinding-dinding yang dengan sengaja tidak di finishing, serta tangga lantai 1 untuk menuju ke lantai 2 juga di dekorasi yang membentuk tumpukan buku dengan tulisan-tulisan bertemakan galaxy luar angkasa. sehingga menambah kesan unik dari desain interior nya bagi para konsumen yang datang.

Menurut Saipul Bahri, desain tangga dalam restoran Eat Happens juga sengaja dibentuk menyerupai tumpukan buku, juduljudul tulisan yang terdapat pada anak tangga tersebut juga diambil dari beberapa judul buku terkenal yang memang membahas seputar galaxy dan kehidupan di luar angkasa. Susunan nya juga disusun mengikuti susunan tata surya yang sesungguhnya, mulai dari anak tangga yang paling bawah dan lebih besar yaitu Matahari hingga anak tangga terkecil yaitu Planet Neptunus, dan di akhiri dengan puncak nya yaitu Galaxy yang bertuliskan Eat Happens Galaxy.

Pada lantai 2 terdapat container bekas yang dijadikan ruang makan tambahan untuk area merokok, container yang telah dimodifikasi dengan lukisan-lukisan yang bertemakan 
galaxy tersebut menarik perhatian pengunjung, ruangan ini juga dijadikan sebagai spot foto bagi konsumen yang datang dan makan di ruangan tersebut. Jika berada di dalam ruangan ini pada sore hingga malam hari, konsumen dapat menikmati suasana malam dengan santai, ruangan ini menghadap jalanan Galaxy, Bekasi. Lampu-lampu pada ruangan ini juga cukup terang dengan warna dominan kuning, sehingga dapat menambah kesan nyaman untuk bersantai dalam jangka waktu yang lama.

Menurut Martin selaku pemilik restoran Eat Happens, ketika ditanyakan mengenai reputasi restoran Eat Happens saat ini dimata konsumen, Martin menjawab bahwa saat ini sudah sesuai dengan apa yang diharapkan pada saat pertama kali membentuk desain interior nya

"Menurut saya sudah ya, karena banyak respon positif yang kami terima, serta dari Word of Mouth (WOM) orang-orang pun sudah jelas mereka tahu bahwa Eat Happens ya seperti ini...banyak kontraktor yang menanyakan konsep dari Eat Happens... beberapa diantaranya mendapatkan projek untuk membuat café seperti Eat Happens, dilihat dari desain nya"

Hal tersebut juga didukung dengan pernyataan dari Christian Taihutu selaku PR dari PT. Urbie Makmur Selaras

"Jelas kami percaya, karena sudah terbukti juga dan kami memang banyak bersosialisasi di media sosial juga seperti di Twitter, dan Instagram, dan zomato. Dan kami juga bukan menyediakan tempat yang sekedar bagus atau makanan yang hanya bagus tampilannya saja, namun kami juga memperhatikan rasa dari makanan tersebut"
Dari pernyataan tersebut, diketahui bahwa restoran Eat Happens juga memperhatikan beberapa aspek pendukung dalam membentuk reputasi restoran, diantaranya adalah penyajian makanan yang menarik namun juga tetap memperhatikan rasa dan kualitas dari makanan nya, kemudian juga menampilkan property desain interior serta suasana restoran yang menarik dan unik untuk menambah kepuasan konsumen hingga mendapatkan feedback baik yang disampaikan oleh konsumen kepada kerabat ataupun keluarganya, hingga terbentuk reputasi yang baik dari keseluruhan aspek yang disampaikan. Karena seorang PR tidak dapat mengendalikan komentar yang disampaikan oleh konsumen kepada calon konsumen lainnya, tetapi seorang PR dapat mengarahkan setiap konsumen untuk memberikan komentar positif yang didasari dengan pelayanan lebih atau dengan kata lain mengutamakan kepuasan konsumen sebagai tiang utama dalam membentuk fondasi reputasi yang kokoh sehingga dapat bertahan lama.

Menurut Saipul Bahri selaku desainer interior restoran Eat Happens juga mengatakan bahwa kaitan desain interior dengan reputasi yang diharapkan dapat tercipta di mata konsumen dan calon konsumen lainnya yaitu dengan memanfaatkan kecenderungan konsumen pada masa ini, dimana konsumen gemar foto-foto dengan interior restoran dan 
mengunggahnya ke sosial media hingga tersebar dengan cepat dan luas, karena pada masa kini berbeda dengan masa yang lalu, konsumen merasa perlu melihat terlebih dahulu seperti apa suasana yang ditawarkan dari suatu restoran yang akan mereka kunjungi, selanjutnya mereka akan mencari tahu mengenai rasa makanan nya. "..tentunya kami ingin menciptakan suatu identitas dan juga perbedaan antara restoran kami dengan restoran lainnya. Desain interior ini juga membantu untuk membentuk dan menaikkan reputasi restoran dimata konsumen, dimana beberapa konsumen memiliki kecenderungan untuk berfoto-foto dan mengunggah foto tersebut ke sosial media"

Beberapa konsumen juga mengatakan bahwa mereka rela mencari informasi terlebih dahulu mengenai restoran yang akan mereka kunjungi, biasanya mereka juga menggunakan aplikasi zomato untuk melihat foto-foto detail restorannya serta rating dan ulasan mengenai restoran tersebut.

“...saya juga biasanya suka mencari informasi mengenai tempat-tempat makan yang unik melalui internet, sayajuga melihat juga dari rating restoran tersebut melalui zomato, Instagram atau rekomendasi temen dari mulut kemulut mengenai desain tempat dan suasana tempat tersebut"

Menurutnya juga, restoran Eat Happens cukup menarik perhatiannya karena lebih terlihat eyecatching jika dibandingkan dengan restoran yang berada disekitarnya, begitu juga dengan konsumen yang bernama Ulfa Damayanti. Ia juga menyempatkan diri untuk mencari informasi terlebih dahulu di google atau zomato mengenai restoran yang akan ia kunjungi.

Menurut Muhammad Ridhwan selaku desainer interior Line Up Studio Desain, desain interior restoran juga termasuk dalam salah satu media komunikasi nonverbal karena adanya pesan yang disampaikan oleh pemilik restoran kepada konsumen nya melalui sentuhan gambar, dekorasi, dan quotes-quotes yang terdapat pada dinding restoran nya.

"..desain interior restoran juga termasuk salah satu media komunikasi nonverbal. Contohnya dalam kasus restoran Eat Happens...pemilik restoran mengkomunikasikan bahwa restoran mereka memiliki konsep berbeda jika dibandingkan dengan restoran yang menawarkan makanan street food disekitarnya, sehingga lebih eyecatching bagi anak muda"

Beberapa media juga pernah meliput desain interior restoran Eat Happens, salah satunya adalah Kompas, Trans TV, ANTV, NET TV dan juga majalah internasional Jepang yang membahas keseluruhan culture dari restoran Eat Happens. Salah satunya adalah Koran Kompas yang meliput restoran Eat Happens Galaxy, membahas mengenai konsep kafe / restoran nya yang unik dan juga rasa nya yang menawan. Dengan adanya liputan koran Kompas, dapat menjangkau calon konsumen restoran Eat Happens yang berada diluar dari Jakarta maupun Bekasi. Hal tersebut juga dapat 
menguntungkan restoran Eat Happens dalam meningkatkan reputasi di mata masyarakat luar.

Selanjutnya adalah Liputan yang dilakukan oleh NET Mediatama dalam acara OK FOOD yang juga di publish di Youtube Netmediatama. Dalam liputan tersebut, pembawa acara bernama Peppy merasa tertarik untuk datang ke restoran Eat Happens karena restoran tersebut telah menarik perhatian nya. Menurutnya, restoran Eat Happens memiliki konsep yang unik serta menjual makanan yang menarik namun tetap dengan kualitas rasanya yang enak.

Dengan terbentuknya reputasi restoran Eat Happens yang baik, maka calon konsumen menjadi tertarik untuk datang ke restoran Eat Happens untuk mengabadikan momen dirinya dan diunggah ke media sosial, dan membagikan momen tersebut kepada temanteman disekitarnya. Saat ini masyarakat sudah semakin kritis dalam mencaritahu hal berdasarkan bukti dan fakta bukan hanya dari sekedar iklan atau promosi biasa. Masyarakat lebih percaya dengan rekomendasi dari orangorang terdekatnya, serta tidak lepas dari peranan media kuliner yang meliput dan sudah lebih dulu membuktikan kebenarannya.

Berdasarkan hasil penelitian, setelah dianalisis bahwa trend yang ada pada masa ini menjelaskan bahwa kini konsumen datang kesuatu restoran tidak lagi didasarkan pada satu alasan saja. Jika biasanya konsumen datang ke restoran hanya untuk menikmati makanan yang dihidangkan, maka saat ini telah berubah. Konsumen datang ke restoran juga untuk menikmati suasana yang ditawarkan dari restoran tersebut, salah satunya adalah dengan memanfaatkan desain interior sebagai objek menarik untuk di foto dan dipamerkan kepada teman-teman lainnya. Beberapa konsumen mengatakan bahwa mereka lebih menyukai restoran dengan desain interior menarik, karena dapat mendukung kegiatan mereka yang gemar foto hal menarik dan unik, serta membagikannya kepada kerabat sekitarnya.

Menurut mereka, desain interior menarik juga dapat memengaruhi mood saat akan menikmati makanan dan juga berkumpul bersama kerabat atau keluarga dalam jangka waktu yang lama. Narasumber mengatakan bahwa mereka mengutamakan desain interior sebagai aspek pertama yang akan mereka cari tahu terlebih dahulu sebelum datang kesuatu restoran, selanjutnya mereka akan mencari tahu mengenai makanan nya. Mereka menyempatkan diri untuk mencari tahu hal detail mengenai restoran yang akan mereka datangi terlebih dahulu, mulai dari foto-foto desain interiornya, menu makanan yang disajikan, hingga ulasan serta rating dari beberapa konsumen yang sudah lebih dulu datang ke restoran tersebut. Mereka mencari tahu dengan memanfaatkan aplikasi kuliner seperti zomato, akun kuliner di 
Instagram dan juga melalui pencarian google.

Berdasarkan hasil wawancara dari beberapa narasumber, restoran Eat Happens memiliki desain interior yang cukup menarik perhatian para konsumen, tidak sedikit orang yang datang ke restoran Eat Happens untuk fotofoto dengan desain interiornya juga makanan nya yang disajikan secara unik dan menarik. Hal ini dibuktikan dengan adanya akun Instagram milik Eat Happens yang mengunggah ulang foto-foto konsumen nya yang menyempatkan diri untuk memasukan foto momen nya selama berada di Eat Happens kedalam sosial media dan menandai akun Instagram Eat Happens.

Konsumen saat ini juga lebih kritis dalam memilih restoran, mereka lebih percaya rekomendasi dari kerabat dekatnya dibandingkan dengan iklan. Selain kritis dalam memilih tempat untuk berkumpul, kebanyakan orang juga memilih tempat yang unik dan terkenal dengan alasan untuk di unggah ke sosial media dan dipamerkan kepada temanteman lainnya. Bila pada awalnya konsumsi dimaknai sebagai proses pemenuhan kebutuhan pokok, maka kini konsumsi dialih fungsikan sebagai sarana mengekspresikan identitas diri seseorang dimata masyarakat.

Sejumlah konsumen mengatakan bahwa saat mereka menemukan objek yang bagus untuk di foto ketika berada di suatu restoran, dengan sengaja mereka akan mengunggah foto tersebut dan disebarkan melalui sosial media. Mereka memiliki harapan bahwa mereka akan dilihat lebih up-to-date dan dibandingkan dengan teman-teman nya. Secara tidak langsung mereka menginginkan untuk mendapatkan pengakuan dari orang lain bahwa mereka lebih kekinian sehingga akan mendapatkan pujian dan simpatik dari orang-orang disekitarnya.

Penampilan suatu restoran yang berbeda dengan yang lain dianggap lebih penting karena apa yang ditampilkan dari restoran tersebut dapat membentuk citra diri seseorang dan menggambarkan reputasi dirinya. Karena objek tersebut memiliki reputasi yang baik sekaligus membawa status bagi orang yang mengkonsumsinya. Saat ini, konsumen menginginkan tempat makan yang menjual makanan enak, namun juga memiliki hal unik dan menarik yang dapat dipamerkan, selanjutnya tempat yang juga mendukung wi-fi untuk update di media sosial dan juga suasana mendukung untuk nongkrong dalam waktu yang lama. Adanya media sosial masyarakat mulai memilih untuk berada di depan laptop atau gadget selama berjam-jam untuk mendaftar pada situs online mall, memilih produk, memasukkan ke dalam troli virtual, mengisi formulir untuk berbelanja, melakukan pembayaran, dan menunggu pengiriman barang yang dipesan selama beberapa hari, daripada ke luar rumah atau mengantri di depan kasir 
toko (Christiani, 2018). Hal tersebutlah yang dimaksudkan bahwa konsumen sekarang lebih gemar mengkonsumsi 'tanda' yang memiliki arti dan makna sosial bagi dirinya dan orangorang disekitarnya (symbolic exchange).

Semakin banyak yang membicarakan restoran Eat Happens, maka semakin viral restoran ini di mata masyarakat. Dari hasil wawancara, setiap konsumen menjawab dengan respon positif mengenai desain interior dan suasana yang ditawarkan dari restoran Eat Happens, termasuk juga rasa dan penyajian makanan nya. Selain konsumen, beberapa media juga tertarik untuk meliput restoran Eat Happens, dan respon dari media tersebut juga positif. Media penasaran dengan pengunjung yang ramai, dan pada saat makanan dihidangkan mereka juga mengapresiasi display dan penyajian makanan nya karena bentuknya yang unik.

Mulanya konsumen telah mengetahui dan mendengar dari teman-temannya mengenai restoran Eat Happens, selanjutnya konsumen membentuk simulasi didalam pikiran mereka saat mereka masih berada dirumah, mereka membayangkan memesan makanan yang unik tersebut dengan suasana yang menyenangkan, nongkrong bersama teman dengan waktu lama dan sibuk mencari spot foto yang bagus melalui aplikasi Zomato, Google, maupun Instagram. Sesampainya disana, simulasi yang telah terbentuk didalam benaknya diharapkan sesuai dengan kenyataan, atau bisa melebihi ekspektasi sehingga terjadi value exchange. Pada awalnya mereka hanya ingin memesan salah satu menu makanan saja, namun ketika melihat menu dan penyajian makanan nya, mereka bisa saja berubah pikiran saat itu juga untuk memesan menu yang lainnya.

Beberapa desainer interior yang mendapatkan projek untuk membangun sebuah restoran juga datang ke restoran ini untuk mendapatkan inspirasi konsep bangunan, dekorasi, desain seperti restoran Eat Happens. Pemilik restoran Eat Happens pun menerima dengan senang hati, dan ia merasa bahwa ini adalah salah satu bentuk apresiasi bagi restoran Eat Happens yang dijadikan contoh. Namun, dengan pencapaian reputasi baik dalam jangka waktu yang lumayan singkat, tidak membuat pemilik restoran Eat Happens merasa puas begitu saja. Menurutnya, restoran Eat Happens masih terus berinovasi agar dapat mempertahankan reputasi yang telah dibangun, serta menjangkau konsumen lebih banyak lagi, serta mempertahankan kesetiaan konsumen agar tidak merasa bosan dan kembali lagi menikmati beberapa menu baru nantinya.

Pemilik restoran Eat Happens merasa perlu meningkatkan mutu kualitas pelayanan, selalu peka terhadap trend yang sedang berkembang, dan juga memberikan suasana yang dapat 
membuat konsumen merasa nyaman berada di area restoran, seperti memberikan ambiance yang baik. Disesuaikan dengan identitas dan ciri khas restoran tersebut yang turut melibatkan desain interior ruangan restoran.

Berdasarkan hasil analisis diatas peneliti mendapatkan sebuah temuan yaitu masyarakat konsumsi saat ini memang lebih kritis dalam memilih sebuah tempat makan, bukan hanya sekedar untuk makan tapi juga karena adanya keinginan untuk mengikuti lingkungan sosial dan berusaha untuk berada di dalam status sosial tertentu. Setelah diteliti, terdapat hal pendukung yang juga mendorong masyarakat tersebut untuk mencapai status sosial tertentu yaitu media baru. Media baru membantu membentuk simulasi awal secara simbolik di benak masyarakat konsumsi. Symbolic exchange terjadi pada saat konsumen datang dan membeli produk dan suasana restoran untuk mewujudkan apa yang telah di simulasikan sebelumnya. Media baru juga berperan dalam mendorong diri pribadi seseorang melakukan sebuah pertimbangan untuk memilih tempat makan dan mendukung simulasi awal. Salah satunya adalah media sosial dan aplikasi penunjang yang membahas setiap destinasi kuliner mulai dari suasana yang di tawarkan, daftar menu, pelayanan hingga harga dan kualitas menurut sejumlah konsumen yang sudah lebih dahulu datang ke tempat makan tersebut. Pencahayaan yang baik dalam desain interior juga dapat mendukung suasana restoran bagi kenyamanan konsumen, property yang dipilih juga harus sesuai dengan konsep dan tema restoran.

Dalam penelitian ini, restoran Eat Happens menjadi destinasi kuliner favorit bagi remaja hingga orang kantoran yang datang bersama kerabat atau keluarganya. Beberapa konsumen mengatakan bahwa biasanya mereka melihat terlebih dahulu setiap penilaian yang telah diberikan kepada restoran Eat Happens dari setiap konsumen yang sudah pernah makan di sana sebelum datang langsung ke restoran Eat Happens. Selanjutnya, mereka melihat seberapa baik rating yang diberikan, karena rating tersebut dapat dijadikan alasan setiap konsumen untuk datang atau tidak ke restoran Eat Happens. Rating dapat terlihat melalui aplikasi Zomato, dan juga pencarian Google. Sejauh ini respon yang diberikan oleh konsumen kepada restoran Eat Happens baik melalui sosial media ataupun aplikasi dan pencarian google bernada positif dan dengan rating yang baik. Hal ini dapat membantu restoran untuk menaikkan dan mempertahankan reputasi baik nya dimata calon konsumen lain nya. Banyaknya media yang meliput juga memengaruhi reputasi restoran Eat Happens, selanjutnya Eat Happens juga semakin banyak dikenal oleh masyarakat.

Desain interior memang menjadi penting bagi sejumlah konsumen, namun restoran Eat 
Happens tidak hanya fokus kepada display desain interior saja tetapi juga memperhatikan cita rasa makanan yang disajikan untuk mempertahankan loyalitas konsumen. Banyaknya jumlah konsumen yang rela mengantri dan masuk kedalam daftar waiting list yang panjang adalah bentuk loyalitas mereka kepada restoran, beberapa konsumen juga mau menyempatkan diri untuk kembali ke restoran Eat Happens dengan mengajak beberapa kerabat dan keluarganya. Dengan adanya desain interior menarik, dapat menjadi medium komunikasi nonverbal yang diterima baik di benak konsumen sehingga adanya pertukaran value dan symbol. Bagi sejumlah konsumen, hal tersebut dapat mendukung identitas diri konsumen ketika ia ikut mengkonsumsi setiap tanda yang mengandung suatu makna tertentu yang menjadi sebuah penilaian baik di mata lingkungan nya. Konsumen loyal terbentuk melalui kepuasan, kenyamanan dan simulasi bahwa hal tersebut sudah menjadi suatu kebutuhan baru bagi konsumen karena suatu display.

\section{SIMPULAN}

Penggunaan desain interior dianggap menjadi penting untuk memberikan kesan pertama yang baik kepada konsumen, dan menjadi sebuah komunikasi nonverbal restoran kepada konsumen yang dapat membentuk reputasi restoran Eat Happens. Pada awalnya, sebelum datang ke restoran Eat Happens, konsumen mencari tahu tentang desain interior suatu restoran yang akan dikunjungi, saat itu juga konsumen telah memiliki simulasi dalam pikirannya, membayangkan ketika berada di restoran tersebut dengan memilih tempat duduk dengan desain interior yang unik dan menikmati makanan yang diinginkan. Saat konsumen tiba di restoran Eat Happens, konsumen dihadapkan dengan desain besarnya terlebih dahulu, yaitu visual gedung dan lighting yang menarik perhatian dari kejauhan.

Kemudian, konsumen mulai mencocokan simulasi yang sudah terbentuk di benak nya tadi, dengan keadaan yang nyata mengenai desain interior restoran tersebut. Setelah konsumen masuk, konsumen juga langsung dihadapkan pada tata letak dan booth yang memiliki desain interior berbeda-beda hingga konsumen merasa penasaran dan mau mengunjungi setiap booth yang ada. Saat konsumen mulai merasa nyaman berada di restoran Eat Happens dalam jangka waktu yang lama, konsumen akan memberikan feedback yang baik kepada restoran dengan cara kembali ke restoran Eat Happens secara berkala serta merekomendasikan restoran Eat Happens kepada teman-teman lainnya yang secara tidak langsung juga dapat membentuk reputasi yang baik bagi restoran Eat Happens.

Setelah melakukan penelitian, peneliti 
menyadari bahwa selain karena display, masyarakat menjadi semakin konsumtif juga karena adanya dorongan dari kehadiran media baru, dimana media baru ternyata juga memiliki peran dalam menampilkan dan menyebarluaskan visual dari desain interior suatu restoran yang didukung dengan ruang lingkup yang sangat luas, dan dengan waktu yang sangat cepat, oleh karena itu peneliti menyarankan agar penelitian berikutnya yang mengangkat tema serupa dapat mengkaji teori Jean Baudrillard secara lebih dalam dan mengkaitkannya dengan teori new media (media baru) dan dikaji secara lebih detail. Karena, display dan new media memiliki pengaruh besar dalam kehidupan masyarakat serta berpengaruh terhadap reputasi perusahaan.

Berdasarkan temuan dalam penelitian ini, peneliti juga menyarankan kepada pebisnis kuliner agar dapat lebih memperhatikan desain interior, karena hal tersebut berkaitan dengan reputasi restoran. Sedangkan untuk konsumen, peneliti berharap agar setiap konsumen dapat menyadari bahwa saat ini karena adanya pengaruh display dan perubahan trend dalam menikmati dan mengkonsumsi makanan, konsumen menjadi semakin konsumtif dan menghilangkan arti konsumsi yang sesungguhnya. Sehingga peneliti menyarankan bahwa seharusnya konsumen juga lebih memperhatikan makanan nya, jangan hanya karena display desain interiornya saja, sehingga konsumen dapat lebih objektif dalam menilai dan membantu meningkatkan kualitas bisnis kuliner untuk berkembang lebih baik.

\section{DAFTAR PUSTAKA}

Anggraeni, A., \& Hermiati, T. (2013). Pengaruh kondisi interior terhadap minat beli ulang konsumen black house cafe. Skripsi. Depok: Universitas Indonesia.

Ardianto, E. (2007). Dasar-dasar public relations. Bandung: Simbiosa Rekatama Media.

Ardianto, E. (2011). Handbook of public relations: pengantar komprehensif. Bandung: Simbiosa Rekatama Media.

Ardianto, E. (2014). Metodologi penelitian untuk public relations kuantitatif dan kualitatif. Bandung: Simbiosa Rekatama Media.

Ayutiani, D. N., Primadani, B., \& Putri, S. (2018). Penggunaan akun instagram sebagai media informasi wisata kuliner. Jurnal PRofesi Humas, 3(1), 39-59.

Baudrillard, J.(2010). Simulacra and simulation. Michigan: University of Michigan Press.

Christiani, L. C. (2018). Dimensi McDonalisasi Lazada Online Mall: sebuah model moderenisasi sistem belanja. Jurnal Komunikasi Dan Kajian Media, 2(1), 1831.

Creswell, J. W. (2014). Research design: qualitative, quantitative, and mixed methods approach (4th ed.). London: Sage Publication, Inc.

Eat Happens Food Place Galaxy. (2019). Retrieved January 2, 2019, from https:// www.zomato.com/jakarta/eat-happensfood-place-bekasi-selatan-bekasi

Eddyono, A. S. (2011). Strategi jaringan 
radio komunitas Indonesia (JRKI) dalam menyelamatkan eksistensi radio komunitas. Jurnal Komunikator, 4(1), 1-13.

Hamid, F., \& Budianto, H. (Eds.). (2011). Ilmu komunikasi sekarang dan tantangan masa depan. Jakarta: Kencana Prenada Media Group.

Kotler, P., \& Keller, K. L. (2012). Marketing Management 15 Global Edition. New Jersey: Prentice Hall. https://doi. org/10.1080/08911760903022556

Kountur, R. (2007). Metode penelitian untuk penulisan skripsi dan tesis. Jakarta: PPM.

Marsum, W. (2010). Restoran dan Segala Permasalahannya. Yogyakarta: Andi Offset.

Meldarianda, R., \& Lisan S, H. (2010). Pengaruh store atmosphere terhadap minat beli konsumen pada resort café atmosphere Bandung. Jurnal Bisnis Dan Ekonomi (JBE), 17(2), 97-108.

Miles, M. B., Huberman, A. M., \& Saldana, J. M. (2015). Qualitative data analysis : a methods sourcebook (3rd ed.). Thousand
Oaks, United States: Sage Publication, Inc. Mulyana, D., \& Rakhmat, J. (Eds.). (2005). Komunikasi antarbudaya. Bandung: Remaja Rosdakarya.

Prasetyo, S. A. (2016). Kajian desain interior restoran piazza Italia dan brandi pizzeria di Surabaya. Jurnal Intra, 4(1), 7-15.

Purwanto, D. (2011). Komunikasi bisnis. Jakarta: Erlangga.

Sugiyono. (2015). Metode penelitian kualitatif. Bandung: Alfabeta.

Sukma, E. A., Fauzi, A., \& Yaningwati, F. (2012). Suasana toko dalam menciptakan emosi dan pengaruhnya terhadap keputusan pembelian. Jurnal Profit, 6(1), 60-87.

Tresnawati, Y., \& Prasetyo, K. (2018). Pemetaan konten promosi digital bisnis kuliner kika's catering di media sosial. PRofesi Humas, 3(1), 102-119.

Wicaksono, A.A. \& Tisnawati, E. (2014). Teori interior. Jakarta: Griya Kreasi. 